\title{
Spatial Analysis of the Ship Gas Emission Inventory in the Port of Busan Using Bottom-Up Approach Based on AIS Data
}

\author{
Donghan Woo and Namkyun Im *(D) \\ Department of Navigation Science, Mokpo National Maritime University, Mokpo 58628, Korea; \\ woodh@mmu.ac.kr \\ * Correspondence: namkyun.im@mmu.ac.kr; Tel.: +82-61-240-6311
}

Citation: Woo, D.; Im, N. Spatial Analysis of the Ship Gas Emission Inventory in the Port of Busan Using Bottom-Up Approach Based on AIS Data. J. Mar. Sci. Eng. 2021, 9, 1457. https://doi.org/10.3390/jmse9121457

Academic Editor: Kostas Belibassakis

Received: 26 November 2021 Accepted: 15 December 2021 Published: 20 December 2021

Publisher's Note: MDPI stays neutral with regard to jurisdictional claims in published maps and institutional affiliations.

Copyright: (c) 2021 by the authors. Licensee MDPI, Basel, Switzerland. This article is an open access article distributed under the terms and conditions of the Creative Commons Attribution (CC BY) license (https:// creativecommons.org/licenses/by/ $4.0 /)$.

\begin{abstract}
Dense hub port-cities have been suffering from ship gas emissions causing atmospheric pollution and a threat to the health of coastal residents. To control ship gas emissions, many regulations have been established internationally. Analyses of ship gas emission inventories are essential to quantify mass and track emission changes over time in a given geographical area. Based on the gas emissions inventory, applicable regulations such as Emission Control Area (ECA) realization and Vessel Speed Reduction (VSR) may be established. The ship gas emission inventory $\left(\mathrm{CO}_{2}, \mathrm{CO}, \mathrm{NO}_{\mathrm{x}}, \mathrm{SO}_{\mathrm{x}}\right.$ and $\left.\mathrm{PM}\right)$ from the Busan Port (BP), including the North Port (NP) and Gamcheon Dadae-po Port (GDP), which is the biggest port in the Republic of Korea and which is also surrounded by residential, commercial, and industrial areas, were spatially analyzed. To calculate geographical ship gas emissions in real-time, this study introduces a bottom-up methodology using Automatic Identification System (AIS) data. According to the geographical density analysis of the gas emissions inventory, this study highlights that about 35\% of the annual ship gas emissions of BP in 2019 were concentrated in the passageway to NP because of high ship speeds when leaving or arriving at the port. To protect the health of coastal residents, ship speed limit regulations along the passageway should be revised based on our spatial analysis results. The spatial analysis of the ship gas emission inventory in BP will be useful basic data for properly evaluating the local gas emission state on newly established or revised environmental regulations for BP.
\end{abstract}

Keywords: air pollution; greenhouse gases (GHGs); ship gas emission; Automatic Identification System (AIS); spatial analysis

\section{Introduction}

Regarding $\mathrm{CO}_{2}$ emissions per weight-unit of cargo, the shipping industry is considered the most eco-friendly and efficient transportation system [1-3]. However, $\mathrm{CO}_{2}$ emissions from shipping have reached $2.89 \%$ of worldwide $\mathrm{CO}_{2}$ emissions [4]. Increasing energy prices have led to the enhancement of energy efficiency in many ports [5-7]. Additionally, concern about the impact of ship gas emissions $\left(\mathrm{CO}, \mathrm{NO}_{x}, \mathrm{SO}_{\mathrm{x}}\right.$ and $\left.\mathrm{PM}\right)$ on the health in residents port cities has been increasing worldwide. Thus, regulations to limit ship gas emissions threatening have received attention from the public and researchers working in various fields [8-10].

Gas emissions caused by shipping have been actively analyzed by the International Maritime Organization (IMO) since 2018 in order to establish a long-term plan to manage such emissions starting in 2023 [2]. The European Union (EU) is leading efforts to control marine gas emissions. The EU has been implementing regulations, namely monitoring, reporting, and verification (MRV), for ships with over 5000 gross tonnages to report and verify $\mathrm{CO}_{2}$ emission every year since 2015. If regulations limiting marine gas emissions are not established by the IMO by 2023, the EU plans to apply the EU emission trading system which originally proposed a cap and trade system for shipping [2].

The Korean government has implemented environmental regulations to protect people from harmful air pollutants. The "Air Quality Management Basic Plan" contains legislation 
which was introduced in 2015 and will remain in effect until 2024. The Korean government has introduced a top-down approach to estimate the quantity of air pollution; however, this method, which fails to consider ship movement, has led to inconsistencies and uncertainty [11]. This demonstrates the importance of estimation approach choice and the accuracy of traffic data used in estimations [12].

Considerable efforts have been made to achieve technological advancements such as accurately estimating marine gas emissions, e.g., by on-board surveys of fuel consumption and action, and field-testing and reviewing ship emission factors [13-15]. There are two major approaches; top-down and bottom-up. The top-down approach is based on the quantity and type of marine fuel sales and fuel-related emission factors [16]. This approach was widely introduced to estimate global and national emissions in the late 1900s and 2000s [10,17-19]. However, the top-down approach does not reflect the real movement of ships. Thus, emission estimations using this approach are considered to contain uncertainties $[18,20]$. The bottom-up approach, on the other hand, overcomes these limitations. This approach uses Automatic Identification System data including real-time ship information (e.g., Maritime Mobility Service Identity (MMSI), status, speed, ship type, breadth, draft, length, gross tonnage, and engine characteristic). Hence, calculated gas emissions reflect each ship's specific conditions in real-time. In other words, the bottom-up approach has higher accuracy than the top-down approach because it requires detailed and exhaustive input such as ship specification data [11,12,21].

The bottom-up approach has been used to precisely analyze marine gas emission inventories in areas with high levels of shipping activities. The $\mathrm{NO}_{\mathrm{x}}, \mathrm{SO}_{2}, \mathrm{CO}_{2}, \mathrm{HC}$ and PM emissions from 7520 ships were estimated in 2007 using the bottom-up approach [22]. Tzannatos [23] applied an in-port ship activity-based methodology for the maneuvering and hoteling of passenger ships and cruise ships in the port of Piraeus, to estimate ship exhaust pollutants, i.e., $\mathrm{NO}_{x}, \mathrm{SO}_{2}$ and PM2.5, in 2008. Kilic and Deniz [24] estimated the spatial distribution of $\mathrm{NO}_{\mathrm{x}}$ according to ship statutes within the Gulf region to determine the most affected areas. In 2007, detailed maritime emission inventories of $\mathrm{NO}_{\mathrm{x}}, \mathrm{SO}_{2}$ and PM10 for ocean-going vessels in Hong Kong were compiled using real-time vessel specifications from AIS data [25]. Berechman and Tseng [26] estimated the annual emission cost of ships and trucks operating in the port of Kaoshiung in Taiwan by using the bottomup methodology. In 2007, exhaust gas emissions from ships in Izmir port in Turkey were calculated by the ship activity-based methodology [27]. Castells et al. [28] quantified polluting emissions ( $\mathrm{NO}_{\mathrm{x}}, \mathrm{SO}_{2}, \mathrm{PM} 2.5$ and VOCs) to estimate the impact of pollution from territorial ships on the densely populated harbor. To evaluate the social cost of cruise ship air emissions, a total in-port emission inventory of cruise shipping was analyzed in terms of gas species, seasonality, and activity using the bottom-up approach [29]. Tichavska and Tovar [30] assessed exhaust pollutants related to cruise and ferry operations in the port of Las Palmas using the bottom-up approach. Fan et al. [31] demonstrated the potential environmental influence of ship emissions on the atmospheric environment surrounding the Yantze River Delta and the East China Sea within $400 \mathrm{~km}$ of the coastline using the bottom-up methodology. In 2013, the bottom-up methodology was introduced to calculate exhaust pollutant values ( $\mathrm{NO}_{\mathrm{x}}, \mathrm{SO}_{2}$ and PM2.5) during maneuvering and hoteling for international cruise ships in 18 ports in Greece [32].

Li et al. [33] demonstrated the low uncertainties of emission estimates using the topdown approach according to the spatial analysis of an AIS-based ship emission inventory in the Pearl River Delta region in Chian. Dongsheng et al. [15] developed the first high temporal-spatial ship emission inventory in Qingdao port and its adjacent waters using the bottom-up method. Based on AIS data acquired through satellites, Kim et al. [2] spatially compiled an emission inventory due to the use of of liquified natural gas worldwide.

Two marine emission studies have targeted Busan Port (BP) in the past. Lee [34] estimated emissions resulting from the hoteling of large vessels in 2011 and 2012 using the top-down approach. However, this approach did not reflect the real movements of ships. The atmospheric dispersion pattern of ship emissions in BP was analyzed using 
the bottom-up methodology and an advanced nonstate meteorological and air quality modeling system.

This study is territorially limited at the North Port (NP) of BP. Based on AIS data for NP and Gamcheon Dadae-po Port (GDP) in 2019, the bottom-up methodology is introduced to devise a geographical marine gas emissions inventory for five air pollutants $\left(\mathrm{CO}_{2}, \mathrm{CO}\right.$, $\mathrm{NO}_{\mathrm{x}}, \mathrm{SO}_{\mathrm{x}}$ and $\mathrm{PM}$ ) over time. This study indicates that about $35 \%$ of ship gas emissions in BP in 2019 were concentrated in the passageway to NP due to high ship speeds when leaving or arriving at the port. To protect the health of coastal residents, improved Emission Control Area (ECA) policies and regulations regarding vessel speed reduction (VSR) along the passageway should be introduced. The present spatial analysis of ship gas emissions in $\mathrm{BP}$ will provide useful basic data for new or revised environmental regulations for the port.

\section{Spatial Analysis Domain and AIS Data}

\subsection{Analysis Domain}

The analysis domain is within the latitude of $35.00^{\circ}$ to $35.12^{\circ} \mathrm{N}$ and the longitude of $129.00^{\circ}$ to $129.20^{\circ} \mathrm{E}$, as shown in Figure 1.

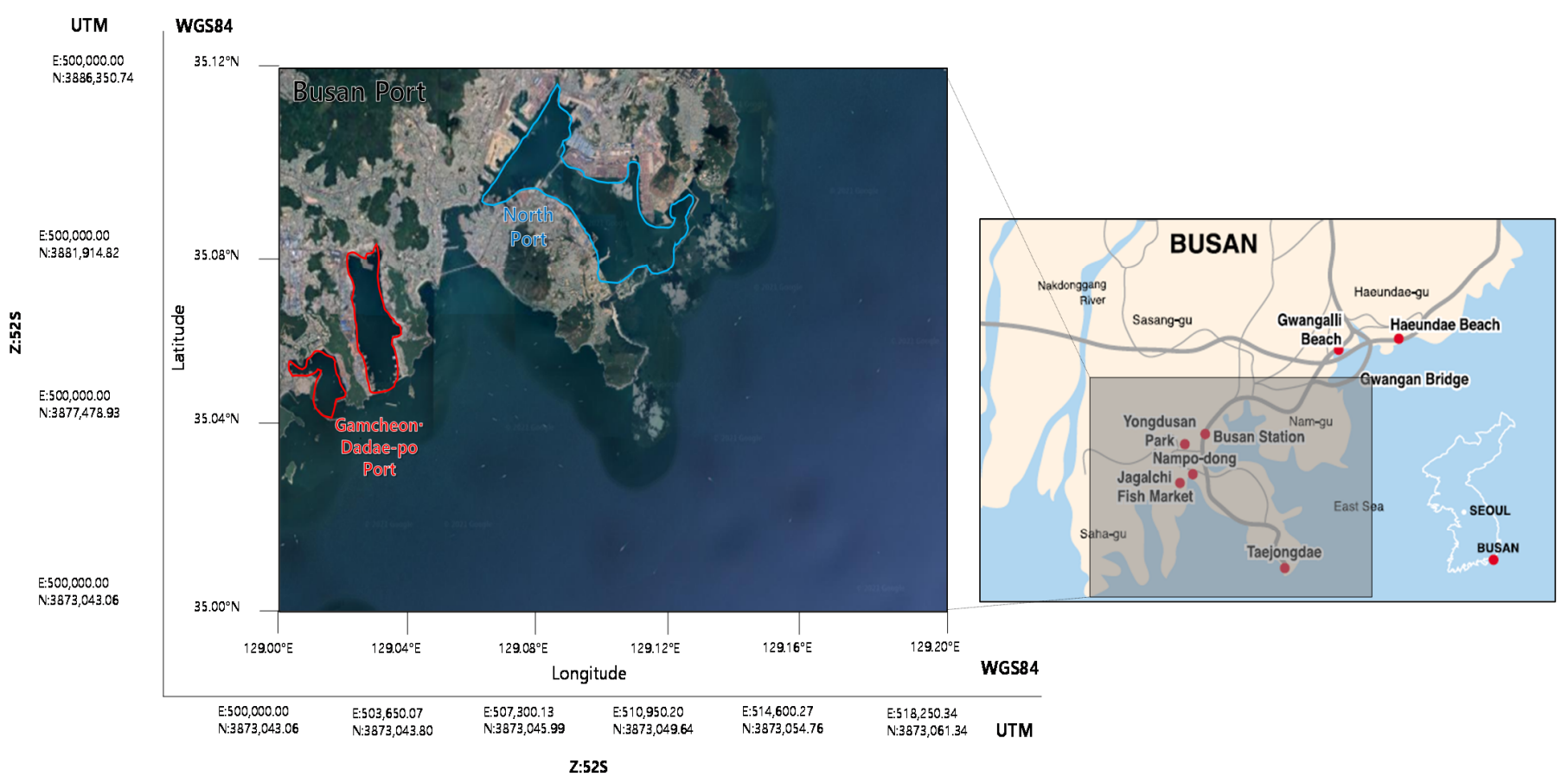

Figure 1. Analysis domain of the Present Study.

BP has a total of 28 berths with a total berth length of $19,886 \mathrm{~m}$. It has two geographical segments, i.e., the North Port (NP) and Gamcheon Dadae-po Port (GDP), with 18 and 10 berths, respectively. The NP primarily handles containers with six berths, servicing container vessels of up to 50,000 Deadweight Ton (DWT) class. The other nine berths of the NP handle raw cargos such as sand, steel, oil, chemicals, and general cargo, and can service a maximum 50,000 DWT. There are three berths for passengers; the cruise berth can service cruise ships up to 80,000 DWT class. The GDP with 10 berths services small and medium container ships and general cargo ships.

Table 1 shows the capacity of the Busan Port and its component ports. The total quantity of container imports and exports in BP in 2019 was about 20 million twenty-foot equivalent units (TEUs), accounting for $32.5 \%$ of the total for the Republic of Korea [35]. The total number of ship entries/departures in BP in 2019 was 93,701. BP handles a significant amount of cargo and has heavy ship traffic. Additionally, it is adjacent to commercial, industrial, and residential areas, namely Yeongdo-gu, Nam-gu, Jung-gu, Dong-gu, Seo-gu and Saha-gu, where the population is about 120,000. Thus, gas emissions in BP have the 
high potential to cause serious health problems including respiratory and cardiovascular diseases, reproductive and central nervous system dysfunctions, and cancer [36].

Table 1. Details of the capacity of Busan Port.

\begin{tabular}{|c|c|c|c|c|}
\hline \multirow[b]{2}{*}{ Port } & \multirow{2}{*}{$\begin{array}{c}\text { Berth } \\
\text { Length (m) }\end{array}$} & \multicolumn{2}{|c|}{ Port Service Capacity } & \multirow[b]{2}{*}{ Sort of Cargo } \\
\hline & & Ship DWT & $\begin{array}{c}\text { Number of } \\
\text { Berth }\end{array}$ & \\
\hline $\begin{array}{c}\text { North Port } \\
\left(\text { Lat } 35.07^{\circ}-35.11^{\circ} \mathrm{N},\right. \\
\left.\text { Lon } 129.06^{\circ}-129.13^{\circ} \mathrm{E}\right)\end{array}$ & 12,954 & $500-80,000$ & 18 & $\begin{array}{c}\text { Container, } \\
\text { Passenger, General, } \\
\text { Chemical, Oil, Raw } \\
\text { (Sand, Fish) }\end{array}$ \\
\hline $\begin{array}{l}\text { Gamcheon Dadae-po Port } \\
\text { (Lat } 35.04^{\circ}-35.08^{\circ} \mathrm{N}, \\
\left.\text { Lon } 129.01^{\circ}-129.04^{\circ} \mathrm{E}\right)\end{array}$ & 6932 & $1000-50,000$ & 10 & $\begin{array}{l}\text { Container, General, } \\
\text { Chemical, Oil, Fish }\end{array}$ \\
\hline
\end{tabular}

\subsection{Automatic Identification System (AIS) Data}

To prevent collisions at sea, the IMO has established a regulation requiring the installation AIS on vessels with gross tonnages of over 300 in international voyages and on domestic cargo vessels with gross tonnages of over 500 not engaged in international voyages. AIS territorially transmits ship data in real-time to allow adjacent vessels to easily recognize a ship's status and movement. AIS has 15 different navigation statuses and transmitting intervals depending on navigation status. AIS data are transmitted and received at intervals of 2-10 s while at sea and $3 \mathrm{~min}$ while anchored.

\subsubsection{AIS Data Description}

In the present study, AIS data were collected within the latitude of $35.00^{\circ}$ to $35.12^{\circ} \mathrm{N}$ and longitudinal of $129.00^{\circ}$ to $129.20^{\circ} \mathrm{E}$ in BP in 2019 by a company named MarineTraffic [37]. The AIS data include Maritime Mobile Service Identity (MMSI), longitude, latitude, vessel name, callsign, vessel type, vessel class, length, width, flag country, destination, estimated time of arrival, draught, speed over ground, course over ground, heading, navigation status, source, time in universal time coordinated (UTC).

Table 2 shows the total number of vessel arrivals for different ship types in the BP region in 2019 based on two data from the AIS and the official statistics of the Korea Maritime Institute (KMI). Figure 2 clearly shows the different between KIM and AIS data. According to the official statistics of the KMI, 47,469 ships arrived in BP. In terms of ship type, $29.3 \%, 23.1 \%, 17.6 \%, 13.6 \%$ and $6.5 \%$ were container, oil tanker, conventional cargo, general cargo, and passenger ships, respectively, as shown in Table 2. Compared to the official statistics from KMI, the breakdown of ship types based on territorial AIS data was found to be similar. The difference in the total number of vessel arrivals in BP between the official KMI statistic and territorial AIS data was $362(+0.73 \%)$. These facts indicate the successful collection of AIS data. Although the difference in the number of fishing vessel arrivals in BP between the two sources was $214(+13.87 \%)$, the impact of emissions from fishing vessels, given that they are much smaller than cargo ships, would be negligible. The discrepancy in the number of fishing vessels was likely caused by fishing vessels that only passed through the port of BP. 
Table 2. Vessel arrivals of different types in BP in 2019.

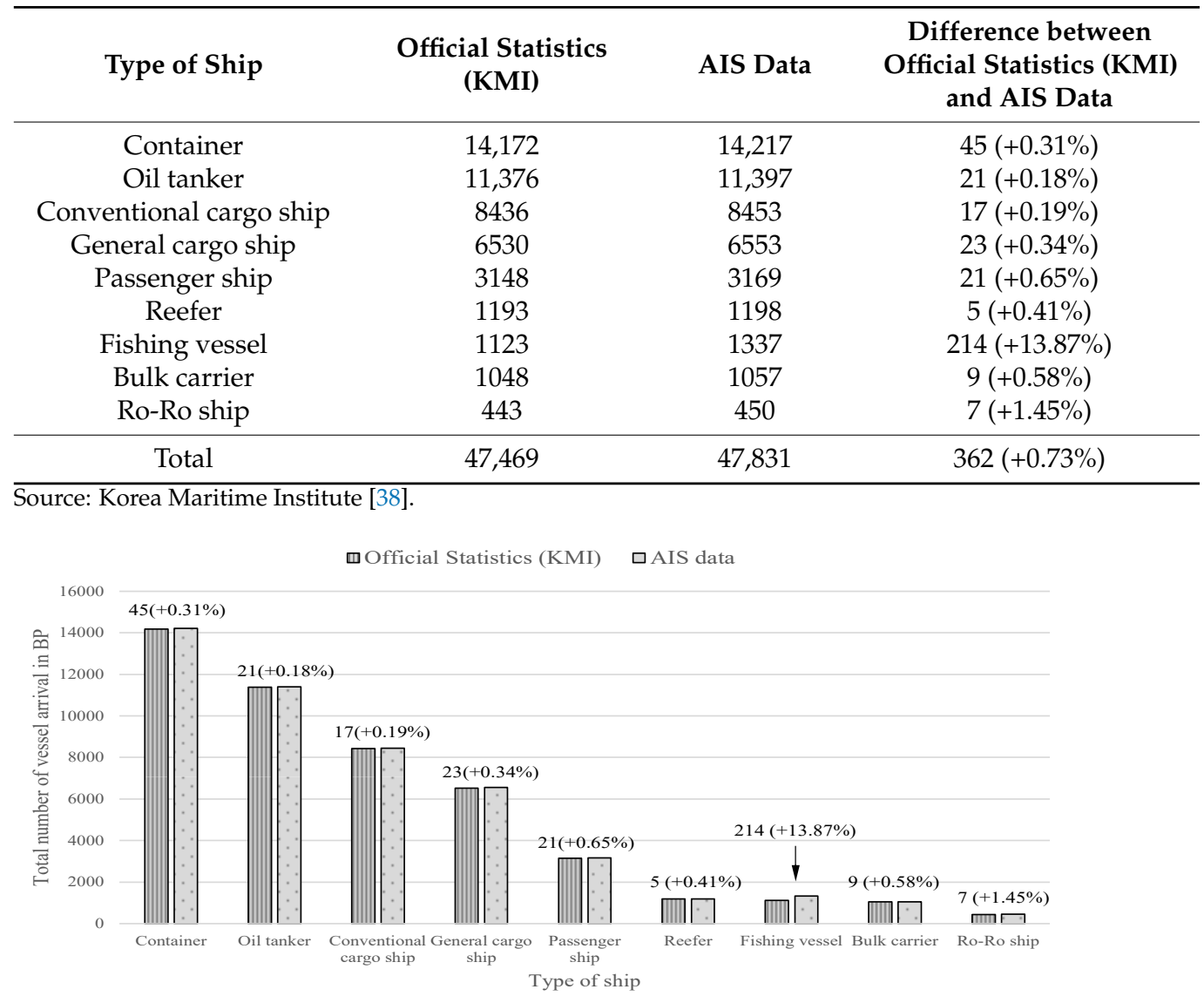

Figure 2. Vessel arrivals of different types between KMI and AIS data in BP in 2019 [38].

\subsubsection{Verification and Revision of AIS Data}

Before using AIS data to calculate ship gas emissions, verification and revision were necessary, because some recorded items in the data were missing or transmitted with error values. For instance, the AIS data of some ships indicated exceptionally high speeds or positions where a ship cannot physically be positioned. Additionally, draught AIS data for some ships were omitted or not properly updated by the ships' navigation officers. Generally, the AIS draught is updated by navigation officers before arrival or departure from a port. It is not automatically updated in real-time. To address these problems, this study conducted AIS data preprocessing, as described below.

- First, $3.5 \%$ of the total AIS data, including the landside position or exceptional deviations from the previous route, are removed.

- Exceptionally high speeds were replaced with averages of previous and subsequent speed data.

- The speed of ships positioned along berth lines or when moored were considered as noise. Thus, their speeds were removed.

- Omitted ship draught data were inputted with their summer draught to conservatively reflect this information. These data were found on the VesselFinder website [39].

\section{Gas Emission Calculations}

\subsection{Bottom-Up Approach}

The bottom-up approach was developed to tackle the limitation of the top-down approach, i.e., the inability to reflect ship movements in real-time in a port for gas emission calculation purposes. Calculations of the amounts of gas emissions using the bottom-up approach could reflect each ship's specific condition in real-time using AIS data. The 
bottom-up approach has higher accuracy than the top-down approach because it requires detailed and exhaustive input, such as ship specification data [11,12,21].

Figure 3 illustrates the procedure for the calculation of spatial gas emissions using the bottom-up approach. Three items, namely, ship position, speed, and draught, were verified and revised to improve the reliability of the data and remove errors. In the second step, AIS data were identified to distinguish ships' navigation statuses, where ' 0 ' means at sea using the main engine, and ' 5 ' means moored; these data were used to devise a suitable gas emission calculation method. With a ' 0 ' status, the total resistance was calculated according to the procedure recommended by the International Towing Tank Conference (ITTC) $[40,41]$. Fuel consumption was calculated according to specific fuel oil consumption (SFOC). Table 3 shows SFOC values by engine year. As the vessel engine gets older, its efficiency is reduced, as shown in Table 3 [1].

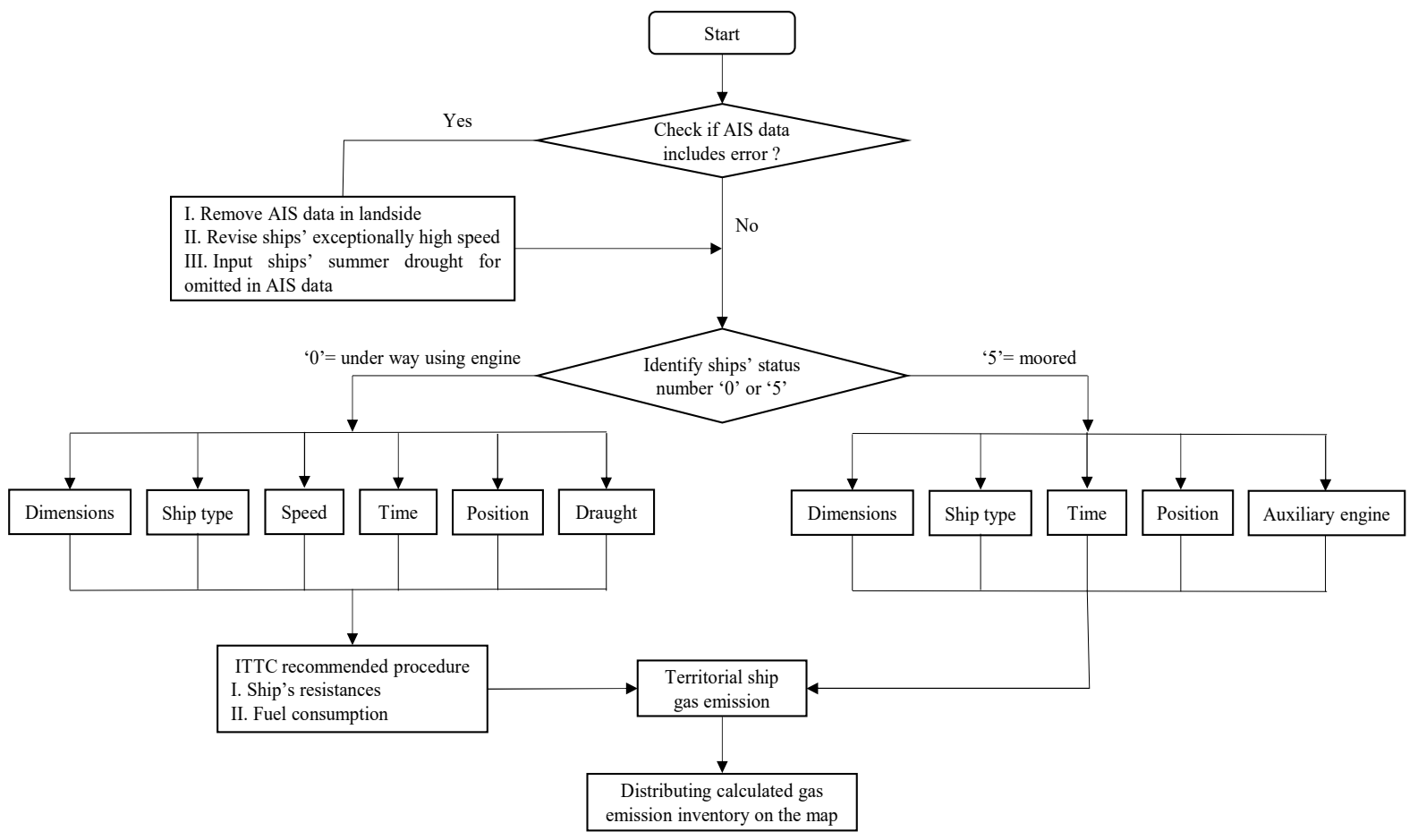

Figure 3. Procedure for the calculation of the spatial gas emission using the bottom-up approach.

Table 3. SFOC values $(\mathrm{g} / \mathrm{kW} \mathrm{h})$ of main engines.

\begin{tabular}{cccc}
\hline Engine Years & Above 15,000 kW & $\mathbf{5 0 0 0 - 1 5 , 0 0 0 ~ k W ~}$ & Below 5000 Kw \\
\hline Before 1983 & 205 & 215 & 225 \\
$1984-2000$ & 185 & 195 & 205 \\
2001-2007 & 175 & 185 & 195 \\
\hline
\end{tabular}

Source: Second IMO greenhouse study, 2009 [1].

Based on the emission factors of each pollutant, the quantities of ship emissions were estimated. In a ship of status ' 5 ', depending on the type of ship, the load factor and average propulsion power of the auxiliary engine were determined. Then, ship gas emissions during mooring were calculated using the emission factors of the auxiliary engine.

\subsection{Gas Emission Calculation Methodology for Maneuvering or Cruising Mode}

At present, there is no local official standard to calculate the gas emissions of ships in the Republic of Korea. The U.S Environmental Protection Agency (EPA) and Euro- 
pean Environment Agency (EEA) [18,42,43] suggested the following equation for ships in maneuvering and cruising mode:

$$
E_{n}=\sum_{i=1}^{n} V A_{i} \times P_{l j} \times L F_{l j m} \times T \times E F_{l j k}
$$

where $E_{n}$ denotes the ship's gas emissions $(\mathrm{kg})$ in maneuvering or cruising mode, $V A_{i}$ denotes the number of a ship's arrival, $P_{l j}$ denotes the average installed engine power $(\mathrm{kW}), L F_{l j m}$ denotes the load factor $(\%), T$ denotes time $(\mathrm{h}), E F_{l j k}$ denotes the emission factor depending on engine and fuel type $(\mathrm{kg} / \mathrm{kWh})$, and $i, j, k, l, m$ and $n$ denote a single voyage, type of engine, type of emission pollutant, size of the ship (DWT), activity mode, and the total number of a ship's arrival, respectively. Table 4 shows the emission factor of each emission pollutant.

Table 4. Emission factors of pollutants.

\begin{tabular}{cc}
\hline Emission Pollutant & Marine HFO Emission Factor (g/g Fuel) \\
\hline $\mathrm{CO}_{2}$ & 3.11400 \\
$\mathrm{CO}$ & 0.00277 \\
$\mathrm{NO}_{x}$ & 0.06512 \\
$\mathrm{SO}_{\mathrm{x}}$ & 0.04908 \\
$\mathrm{PM}$ & 0.00699 \\
\hline
\end{tabular}

Source: Third IMO Greenhouse Gas Study, 2014 [44].

Calculation of Installed Power of Ships Using AIS Data

Molland et al. [45] suggested the following equation to calculate the installed engine power required to produce a desired speed:

$$
P_{i j}=\frac{R_{T} \times V}{\eta_{D} \times \eta_{T}}+m
$$

where $R_{T}$ denotes the total resistance of the ship, $V$ denotes the speed of the ship $(\mathrm{m} / \mathrm{s})$, $\eta_{D}$ denotes the quasi-propulsion coefficient, $\eta_{T}$ denotes the transmission efficiency, and $m$ denotes the sea margin. Typically, the quasi-propulsion coefficient $\eta_{D}$ ranges from 0.55 to 0.65 [46]. Transmission efficiency refers to losses between delivered power at the tail-shaft and the installed engine; it typically ranges from 0.95 to 0.98 [45]. Sea margin $m$ indicates allowances on installed power for roughness, fouling, and weather; this is typically $15-30 \%$, depending on the route [45]. In the present study, to conservatively estimate ship gas emissions, the maximum values of the quasi-propulsion coefficient $\eta_{D}$, the transmission efficiency $\eta_{D}$, and the sea margin $m$ were set in typical ranges, i.e., 0.65 , 0.98 , and $30 \%$, respectively.

The International Towing Tank Conference (ITTC) [40] suggested the following equation to calculate the total resistance of a ship $R_{T}(\mathrm{KN})$ :

$$
R_{T}=0.5 \times C_{T} \times \rho \times S \times V^{2}
$$

where $C_{T}$ denotes the total resistance coefficient, $\rho$ denotes the density of seawater, and $S$ denotes the wetted surface of the ship. The total resistance coefficient $C_{T}$ is calculated by Equation (4) [41]:

$$
C_{T}=C_{F}+C_{A}+C_{A A}+C_{R}
$$

where $C_{F}$ denotes the frictional resistance coefficient, $C_{A}$ denotes the incremental resistance coefficient. $C_{A A}$ denotes the air resistance coefficient, and $C_{R}$ denotes the residual resistance 
coefficient. According to the Reynolds number $R_{n}$, the frictional resistance coefficient $C_{F}$ may be derived by Equation (5) as below:

$$
C_{F}=\frac{0.075}{\left(\log _{10} R_{n}-2\right)^{2}}
$$

The incremental resistance coefficient can be calculated by Equations (6) and (7), depending on the displacement of the ship [47]:

$$
\begin{array}{cc}
C_{A}=10^{-3} \times\left(0.5 \times \log _{10} \Delta-0.1 \times\left(\log _{10} \Delta\right)^{2}\right) & (\Delta<16,000 \text { tons }) \\
C_{A}=10^{-3} \times \operatorname{Maximum}\left(-0.1 ; 0.5 \times \log _{10} \Delta-0.1 \times\left(\log _{10} \Delta\right)^{2}\right) & (\Delta>16,000 \text { tons })
\end{array}
$$

where $\Delta$ denotes the displacement of the ship (in tons). The air resistance coefficient $C_{A A}$ was recommended by Kristensen and Lutzen [41], as shown in Table 5.

Table 5. Air resistance coefficient $C_{A A}$.

\begin{tabular}{cc}
\hline Type of Ship & $C_{A A} \cdot 1000$ \\
\hline Small Tankers & 0.07 \\
Handysize Tankers & 0.07 \\
Handymax Tankers & 0.07 \\
Panamax Tankers & 0.05 \\
Aframax Tankers & 0.05 \\
Suezmax Tankers & 0.05 \\
VLCC & 0.04 \\
Container Vessels & 0.28 TEU $^{-0.126}$ \\
\hline
\end{tabular}

\subsection{Gas Emission Calculation Methodology for Hoteling Mode}

Based on the bottom-up approach, the EPA and EEA $[18,42,43]$ suggested the following equation for ships in hoteling mode:

$$
E_{b}=\sum_{i=1}^{n} V B_{i} \times P_{a} \times L F_{a} \times T \times E F_{a}
$$

where $E_{b}$ denotes the ship's gas emissions $(\mathrm{kg})$ in hoteling mode, $V B_{i}$ denotes the number of times the ship has been hoteled, $P_{a}$ denotes the average installed auxiliary engine power $(\mathrm{kW}), L F_{a}$ denotes the load factor of the auxiliary engine (\%), $T$ denotes time (h), and $E F_{a}$ denotes the emission factor of the auxiliary engine $(\mathrm{kg} / \mathrm{kW} \mathrm{h})$. Table 4 shows the emission factor for each pollutant. Table 6 shows the auxiliary engine power ratios and auxiliary engine load factor in port during hoteling mode [48]. Table 7 shows the emission factor of the auxiliary engine [49]. In the present study, the engine type of ships and the fuel type used during hoteling mode were assumed as medium speed diesel (MSD) and marine diesel oil (MDO), respectively.

Table 6. Auxiliary engine power ratios and load factor in port during hoteling mode.

\begin{tabular}{cccc}
\hline Ship Type & $\begin{array}{c}\text { Average Propulsion } \\
\text { Engine }(\mathbf{k W})\end{array}$ & $\begin{array}{c}\text { Auxiliary to } \\
\text { Propulsion Ratio }\end{array}$ & $\begin{array}{c}\text { Auxiliary Engine } \\
\text { Load Factor }\end{array}$ \\
\hline Container & 30,900 & 0.220 & 0.17 \\
Oil tanker & 9400 & 0.211 & 0.67 \\
Conventional cargo & 6250 & 0.269 & 0.22 \\
ship & 9300 & 0.191 & 0.22 \\
General cargo ship & & & \\
\hline
\end{tabular}


Table 6. Cont.

\begin{tabular}{cccc}
\hline Ship Type & $\begin{array}{c}\text { Average Propulsion } \\
\text { Engine (kW) }\end{array}$ & $\begin{array}{c}\text { Auxiliary to } \\
\text { Propulsion Ratio }\end{array}$ & $\begin{array}{c}\text { Auxiliary Engine } \\
\text { Load Factor }\end{array}$ \\
\hline Passenger ship & 39,600 & 0.278 & 0.64 \\
Reefer & 9600 & 0.406 & 0.34 \\
Bulk carrier & 8000 & 0.222 & 0.22 \\
Ro-Ro ship & 11,000 & 0.259 & 0.34 \\
\hline
\end{tabular}

Source: Nicewicz and Tarnapowicz [48].

Table 7. Auxiliary engine power ratios and load factor in port during hoteling mode.

\begin{tabular}{ccccccc}
\hline \multirow{2}{*}{ Engine Type } & \multirow{2}{*}{ Fuel Type } & \multicolumn{5}{c}{ Emission Factors (g/kW s) } \\
\cline { 3 - 7 } & & $\mathbf{C O}_{\mathbf{2}}$ & $\mathbf{C O}$ & $\mathbf{N O}_{\mathbf{x}}$ & $\mathbf{S O}_{\mathbf{x}}$ & $\mathbf{P M}$ \\
\hline MSD & MDO & 0.17946 & 0.00030 & 0.00360 & 0.00110 & 0.00013 \\
\hline Source: EPA [49]. & & & & &
\end{tabular}

\section{Results and Discussion}

Based on AIS data for BP, which is directly surrounded by residential, commercial, and industrial areas, the bottom-up methodology was introduced to establish a spatial gas emissions inventory $\left(\mathrm{CO}_{2}, \mathrm{CO}, \mathrm{NO}_{\mathrm{x}}, \mathrm{SO}_{\mathrm{x}}\right.$ and $\left.\mathrm{PM}\right)$ for 2019. Such an inventory of $\mathrm{BP}$ will be a useful resource for new or revised long- and short-term environmental regulations regarding ship gas emissions in the port.

\subsection{Fuel Consumption Estimation}

This section describes the fuel consumption estimation in BP in 2019, the results of which were calculated according to formulas applied to two navigation statuses, i.e., (i) maneuvering or cruising, and (ii) hoteling or anchoring. Table 8 shows the estimated annual fuel consumption in BP. More than $70 \%$ of the annual total fuel consumption may be attributed to maneuvering or cruising. About $25 \%$ is used while hoteling, and less than $2 \%$ is consumed while anchoring. As shown in Table 8 , about $35 \%$ of the annual total fuel consumption in BP is concentrated in the passageway to NP; see Figure 4. This is because ship speed was weighted as the main increase factor in the formula utilized in this study, and during arrival or departure, ships increase their speed along the passageway. Figure 5 shows the monthly fuel consumption in BP. As shown in the trend line, there was no significant fluctuation in 2019. However, compared to other months, the monthly fuel consumption in February and December decreased somewhat.

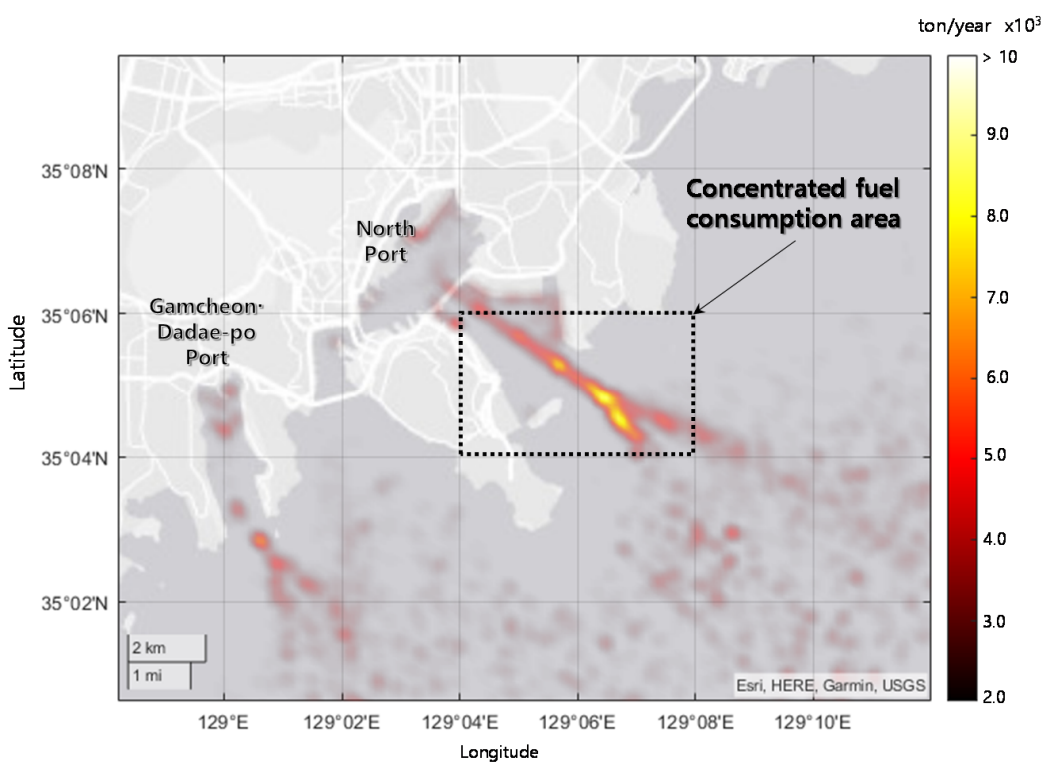

Figure 4. Area of concentrated fuel consumption in BP in 2019. 
Table 8. Fuel consumption depending on navigation statues in BP in 2019.

\begin{tabular}{cc}
\hline Navigation Statues & Fuel Consumption (Ton/Year) \\
\hline Maneuvering or Cruising & $498,615.3(72.0 \%)$ \\
Hoteling & $182,133.1(26.3 \%)$ \\
Anchoring & $11,772.86(1.7 \%)$ \\
\hline Total & $692,521.2$ \\
\hline Area of concentrated fuel consumption & $237,534.8(34.3 \%)$ \\
\hline
\end{tabular}

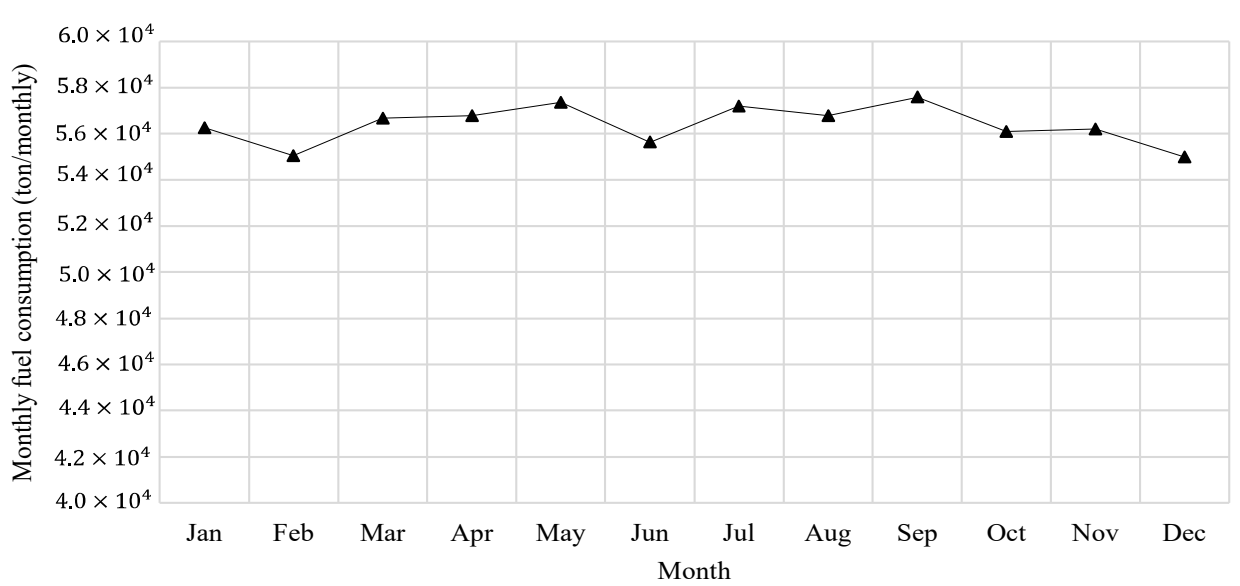

Figure 5. Monthly fuel consumption in BP in 2019.

\subsection{Spatial Marine Gas Emission in BP}

In terms of the contribution to gas emissions by ship type, container and tanker ships accounted for half. Figure 6 shows the proportion of the gas emissions by ship type in BP in 2019. Container and tanker ships emitted about $29.3 \%$ and $27.1 \%$ of all air pollutants, because the main role of the BP is servicing container and oil cargos. The proportion of other ship types, namely, conventional cargo ships, general cargo ships, passenger ships, reefers, fishing vessels, bulk carriers, and Ro-Ro ships, was $22.4 \%, 19.1 \%, 9.0 \%, 2.9 \%, 5.0 \%$, $3.6 \%$ and $1.4 \%$, respectively.

$$
\varpi \mathrm{CO} 2 \backsim \mathrm{NOx} \backsim \mathrm{SOx} \approx \mathrm{PM} \approx \mathrm{CO}
$$

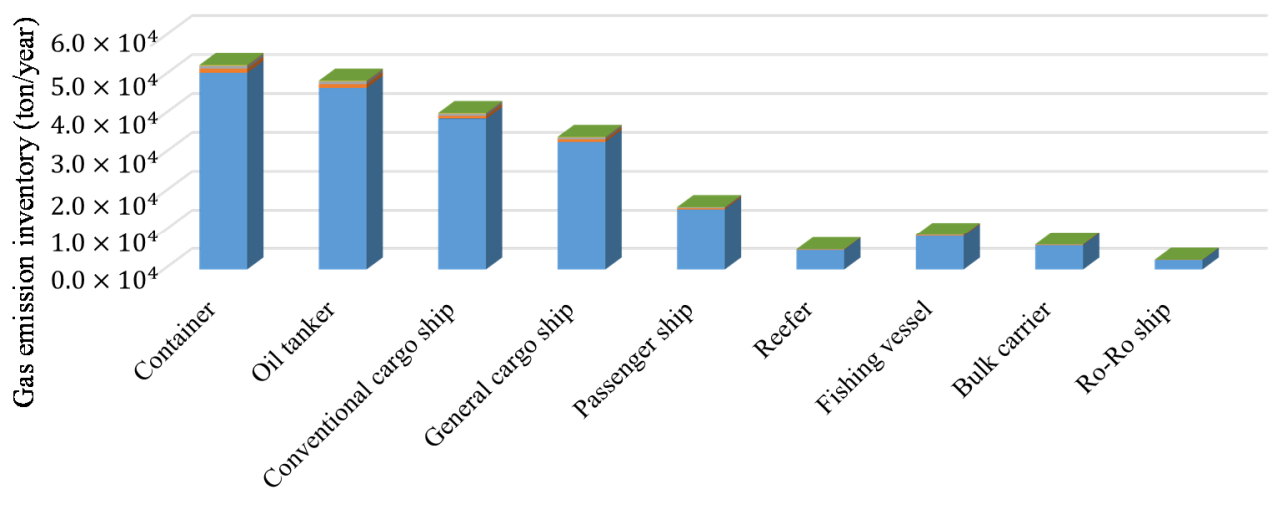

Ship types

Figure 6. Proportion of the gas emission by ship type in BP in 2019.

As shown in Figure 6, the sum of gas emissions of the three types of vessels (fishing vessels, reefers, and general cargo ships) only accounts for $27.0 \%$ of all air pollutants identified in the emission inventory. The main role of the NP is for containers, oil tankers, and conventional cargo ships; thus, gas emissions in the port account for at least $78.0 \%$ of the total for BP. 
This section presents estimations of marine gas emissions in BP in 2019, and spatially describes the result on a map; see Figure 7. This spatial gas emission inventory covers two geographical areas (NP and GDP). It provides data on five air pollutants $\left(\mathrm{CO}_{2}, \mathrm{CO}\right.$, $\mathrm{NO}_{x}, \mathrm{SO}_{x}$ and $\mathrm{PM}$ ) according to estimations of fuel consumption, as evaluated in the above section. The amount of emissions of each air pollutant is described in Table 9. Briefly, in total, 2,074,138 tons of $\mathrm{CO}_{2}, 1845$ tons of $\mathrm{CO}, 43,374$ tons of $\mathrm{NO}_{\mathrm{X}}, 32,691$ tons of $\mathrm{SO}_{\mathrm{X}}$, and 4656 tons of PM were emitted in BP in 2019. Given that $\mathrm{CO}_{2}$ has the highest emission factor ( $3.114 \mathrm{~g} / \mathrm{g}$ fuel), it accounted for $96.17 \%$ of the total air pollutants in BP in 2019. $\mathrm{NO}$ X made up about $2.01 \%$ of the total. The proportions of $\mathrm{CO}, \mathrm{SO}$ and $\mathrm{PM}$ were $0.09 \%, 1.52 \%$ and $0.22 \%$, respectively.
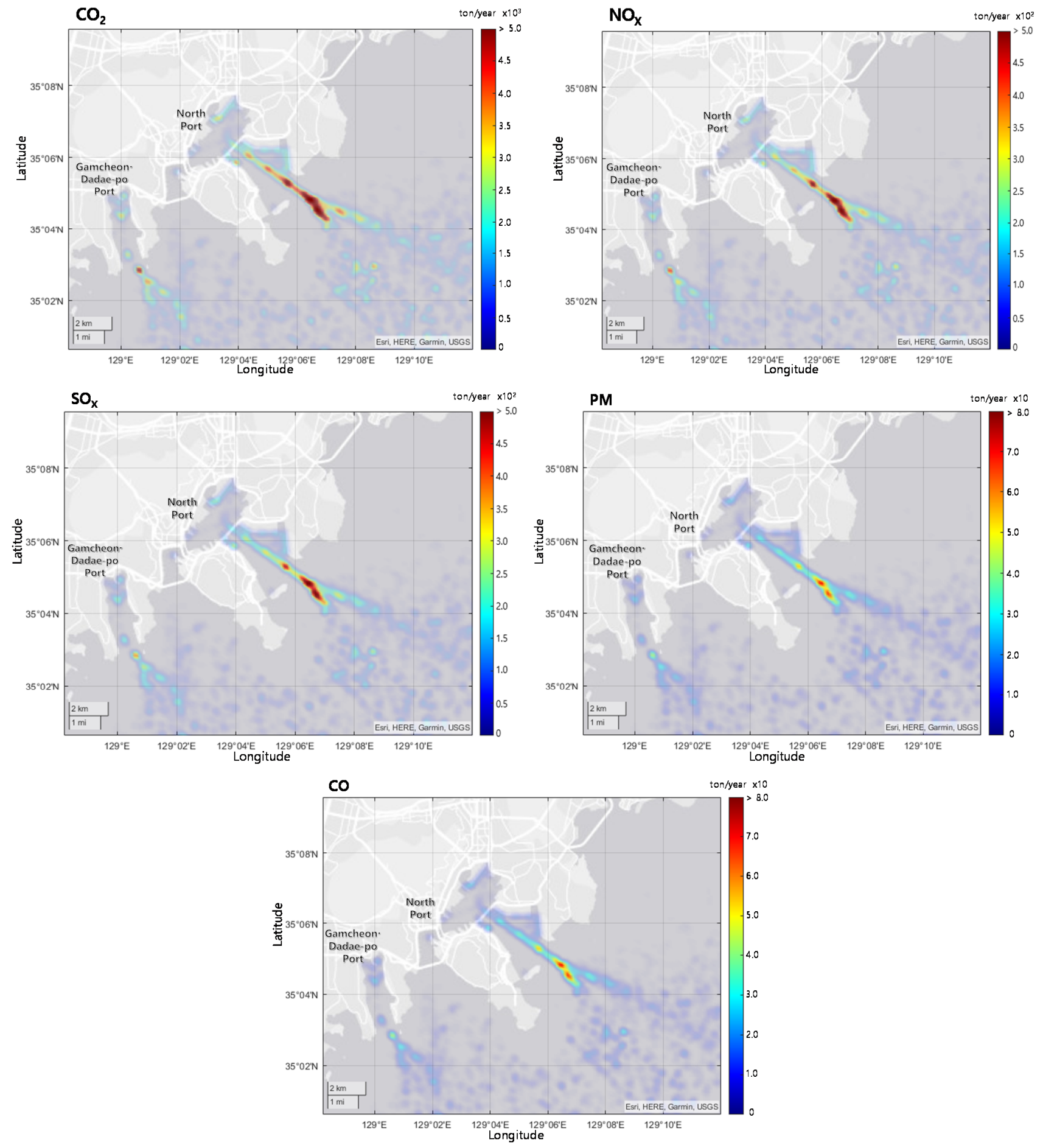

Figure 7. Spatial distribution of $\mathrm{CO}_{2}, \mathrm{CO}, \mathrm{NO}_{X}, \mathrm{SO}_{X}$ and $\mathrm{PM}$ in $\mathrm{BP}$ in 2019. 
Table 9. Marine gas emission inventory from different ship types in BP in 2019.

\begin{tabular}{cccccc}
\hline Ship Type & $\mathbf{C O}_{\mathbf{2}}$ & $\mathbf{C O}$ & $\mathbf{N O}_{\mathbf{X}}$ & $\mathbf{S O}_{\mathbf{X}}$ & $\mathbf{P M}$ \\
\hline Container & 507,264 & 451 & 10,608 & 7995 & 1139 \\
Oil tanker & 468,500 & 417 & 9797 & 7384 & 1052 \\
Conventional cargo ship & 388,682 & 346 & 8128 & 6126 & 872 \\
General cargo ship & 329,685 & 293 & 6894 & 5196 & 740 \\
Passenger ship & 156,167 & 139 & 3266 & 2461 & 351 \\
Reefer & 50,320 & 45 & 1052 & 793 & 113 \\
Fishing vessel & 86,759 & 77 & 1814 & 1367 & 195 \\
Bulk carrier & 62,467 & 56 & 1306 & 985 & 140 \\
Ro-Ro ship & 24,293 & 22 & 508 & 383 & 55 \\
\hline Total & $2,074,138$ & 1845 & 43,374 & 32,691 & 4656 \\
\hline
\end{tabular}

(unit: ton/year).

Figure 7 illustrates the annual spatial distribution of five air pollutants $\left(\mathrm{CO}_{2}, \mathrm{CO}, \mathrm{NO}_{\mathrm{x}}\right.$, $\mathrm{SO}_{\mathrm{x}}$ and $\mathrm{PM}$ ) in $\mathrm{BP}$ in 2019. The emissions of these pollutants are roughly distributed along the berthing line and the passageway of port. Comparing NP and GDP, it can easily be seen that gas emissions are more widespread in the former NP. GDP mainly accommodates fishing vessels, reefers, and general cargo ships.

In terms of areas which experience high concentrations of gas emissions, the five air pollutants were found to be highly distributed along the passageway between the port to the ocean at the NP and GDP. The two ports showed a similar tendency in this respect. As mentioned in Section 4.1, this is because ship speed was weighted as the main increasing factor in the formula utilized in this study, and during arrival or departure, ships typically increase their speed. Previous studies on ship gas emissions while hoteling in BP have focused on the amount of a given pollutant emitted along the berth-line; however, to establish optimal environmental regulations for BP, spatial results must be taken into account. According to the spatial distribution of air pollutants, regulations should be implemented denoting a speed limit area in the port. Additionally, based on the spatial results presented herein, an atmospheric monitoring system should be established at the the optimal location in order to precisely analyze the impact of ship emissions on the port.

\section{Conclusions}

This study aims to propose basic data to establish optimal environmental regulations in Busan Port (BP). To calculate spatial gas emissions of five air pollutants $\left(\mathrm{CO}_{2}, \mathrm{CO}, \mathrm{NO}\right.$, $\mathrm{SO}_{\mathrm{X}}$ and $\mathrm{PM}$ ) in real-time in 2019, this study applied a bottom-up methodology using territorial Automatic Identification System (AIS) data.

The contributions of this study are three-fold:

- Firstly, the calculated gas emission inventory using the bottom-up methodology demonstrated that AIS data are useful for identifying ship characteristics and specific emission factors, which are essential in bottom-up ship emission inventory development.

- Secondly, plotting data from the gas emission inventory on a map provided revealing information about fuel consumption.

- Third, a spatial analysis of the gas mission inventory showed the areas which were affected by high concentrations of emissions.

The following conclusions and recommendations for further studies can be made:

- The gas emission inventory is highly distributed along the passageway between the port to the ocean at the NP and GDP in BP, because ships significantly increase their speed in this area when arriving or departing.

- According to our spatial analysis, regulations for a speed limit area in BP should be implemented to mitigate gas emissions.

- Based on spatial results presented herein, an atmospheric monitoring system should be established at the optimal location in order to precisely analyze the impact of ship emissions on the port. 
To improve the reliability of the calculated gas emission inventory using the bottomup methodology, revising irregular AIS data recoding intervals in the same navigation statute and details of engine type and efficiency are required. Additionally, based on the gas emission inventory, it is necessary to evaluate the atmospheric diffusion pattern of gas emissions, considering local weather data, in order to determine which territory is most likely to be affected by marine pollutants.

Author Contributions: Conceptualization, software, data Curation, investigation, writing-original draft, writing - review and editing: D.W. Conceptualization, investigation, methodology, validation, supervision: N.I. All authors have read and agreed to the published version of the manuscript.

Funding: This research received no external funding.

Data Availability Statement: Not applicable.

Acknowledgments: This work was supported by the National Research Foundation of Korea (NRF) grant funded by the Korea government (MSIT) (NRF-2020R1F1A1050113) titled with "The Technology for Marine Traffic Hazard Control system using Ship navigation Big Data".

Conflicts of Interest: The authors declare no conflict of interest.

\section{References}

1. Buhaug, O.; Corbett, J.J.; Endresen, O.; Eyring, V.; Faber, J.; Hanayama, S.; Lee, D.S.; Lee, D.; Lindstad, H.; Markowska, A.Z.; et al. Second IMO Greenhouse Gas Study 2009; International Maritime Organization: London, UK, 2009; Available online: https: / / www.imo.org/en/OurWork/Environment/Pages/Greenhouse-Gas-Study-2009.aspx (accessed on 14 December 2021).

2. Kim, H.; Watanabe, D.; Toriumi, S.; Hirata, E. Spatial Analysis of an Emission Inventory from Liquefied Natural Gas Fleet Based on Automatic Identification System Database. Sustainability 2021, 13, 1250. [CrossRef]

3. Toscano, D.; Murena, F. Atmospheric ship emissions in ports: A review. Correlation with data of ship traffic. Atmos. Environ. X 2019, 4, 100050. [CrossRef]

4. IMO-MEPC Reduction of GHG emissions from ships. Fourth IMO GHG Study 2020. Int. Marit. Organ. 2020. Available online: https:/ /imoarcticsummit.org/publications/imo-papers/mepc-75/reduction-of-ghg-emissions-from-ships-fourth-imoghg-study-2020-final-report/ (accessed on 14 December 2021).

5. Venturini, G.; Iris, Ç.; Kontovas, C.A.; Larsen, A. The multi-port berth allocation problem with speed optimization and emission considerations. Transp. Res. Part D Transp. Environ. 2017, 54, 142-159. [CrossRef]

6. Golias, M.; Boile, M.; Theofanis, S.; Efstathiou, C. The Berth-scheduling problem maximizing berth productivity and minimizing fuel consumption and emissions production. Transp. Res. Rec. J. Transp. Res. Board 2010, 2166, 20-27. [CrossRef]

7. Iris, Ç.; Lam, J.S.L. A review of energy efficiency in ports: Operational strategies, technologies and energy management systems. Renew. Sustain. Energy Rev. 2019, 112, 170-182. [CrossRef]

8. $\quad$ Eyring, V.; Isaksen, I.S.A.; Berntsen, T.; Collins, W.J.; Corbett, J.J.; Endresen, Ø.; Grainger, R.G.; Moldanova, J.; Schlager, H.; Stevenson, D.S. Transport impacts on atmosphere and climate: Shipping. Atmos. Environ. 2010, 44, 4735-4771. [CrossRef]

9. Saxe, H.; Larsen, T. Air pollution from ships in three Danish ports. Atmos. Environ. 2004, 38, 4057-4067. [CrossRef]

10. Corbett, J.J.; Winebrake, J.J.; Green, E.H.; Kasibhatla, P.; Eyring, V.; Lauer, A. Mortality from Ship Emissions: A Global Assessment. Environ. Sci. Technol. 2007, 41, 8512-8518. [CrossRef]

11. Song, S.K.; Shon, Z.-H. Current and future emission estimates of exhaust gases and particles from shipping at the largest port in Korea. Environ. Sci. Pollut. Res. 2014, 21, 6612-6622. [CrossRef] [PubMed]

12. Lee, H.; Park, D.; Choo, S.; Pham, H.T. Estimation of the Non-Greenhouse Gas Emissions Inventory from Ships in the Port of Incheon. Sustainability 2020, 12, 8231. [CrossRef]

13. Hulskotte, J.; van der Gon, H.D. Fuel consumption and associated emissions from seagoing ships at berth derived from an on-board survey. Atmos. Environ. 2010, 44, 1229-1236. [CrossRef]

14. Cooper, D. Exhaust emissions from ships at berth. Atmos. Environ. 2003, 37, 3817-3830. [CrossRef]

15. Song, S. Ship emissions inventory, social cost and eco-efficiency in Shanghai Yangshan port. Atmos. Environ. 2014, 82, 288-297. [CrossRef]

16. Nunes, R.A.O.; Alvim-Ferraz, M.C.M.; Martins, F.G.; Sousa, S.I.V. The activity-based methodology to assess ship emissions-A review. Environ. Pollut. 2017, 231, 87-103. [CrossRef] [PubMed]

17. Corbett, J.J.; Fischbeck, P. Emissions from ships. Science 1997, 278, 823-824. Available online: https://www.science.org/doi/10.1 126/science.278.5339.823 (accessed on 14 December 2021). [CrossRef]

18. EMEP; EEA. EMEP-EEA Air Pollutant Emission Inventory Guidebook 2019-1.A.3.b.i-iv Road Transport 2019. J. Chem. Inf. Model. 2017, 278, 5339. Available online: https://www.eea.europa.eu/publications/emep-eea-guidebook-2019 (accessed on 14 December 2021). 
19. Endresen, Ø.; Bakke, J.; Sørgård, E.; Berglen, T.F.; Holmvang, P. Improved modelling of ship $\mathrm{SO}_{2}$ emissions-A fuel-based approach. Atmos. Environ. 2005, 39, 3621-3628. [CrossRef]

20. Agency, U.S.E.P. Control of Emissions of Air Pollution from New Marine CompressionIgnition Engines at or above $37 \mathrm{~kW}$; Office of Transportation Air Quality: Ann Arbor, MI, USA, 1999.

21. Liu, T.-K.; Sheu, H.-Y.; Tsai, J.-Y. Sulfur dioxide emission estimates from merchant vessels in a port area and related control strategies. Aerosol Air Qual. Res. 2014, 14, 413-421. [CrossRef]

22. Deniz, C.; Kilic, A.; C1vkaroglu, G. Estimation of shipping emissions in Candarli Gulf, Turkey. Environ. Monit. Assess. 2010, 171, 219-228. [CrossRef]

23. Tzannatos, E. Ship emissions and their externalities for the port of Piraeus-Greece. Atmos. Environ. 2010, 44, 400-407. [CrossRef]

24. Kiliç, A.; Deniz, C. Inventory of shipping emissions in Izmit Gulf, Turkey. Environ. Prog. Sustain. Energy 2010, 29, 221-232. [CrossRef]

25. Yau, P.S.; Lee, S.C.; Corbett, J.J.; Wang, C.; Cheng, Y.; Ho, K.F. Estimation of exhaust emission from ocean-going vessels in Hong Kong. Sci. Total Environ. 2012, 431, 299-306. [CrossRef]

26. Berechman, J.; Tseng, P.-H. Estimating the environmental costs of port related emissions: The case of Kaohsiung. Transp. Res. Part D Transp. Environ. 2012, 17, 35-38. [CrossRef]

27. Saraçoğlu, H.; Deniz, C.; Kılıç, A. An investigation on the effects of ship sourced emissions in izmir port, Turkey. Sci. World J. 2013, 2013, 218324. [CrossRef]

28. Sanabra, M.C.; Santamaría, J.J.U.; De Osés, F.X.M. Manoeuvring and hotelling external costs: Enough for alternative energy sources? Marit. Policy Manag. 2013, 41, 42-60. [CrossRef]

29. Maragkogianni, A.; Papaefthimiou, S. Evaluating the social cost of cruise ships air emissions in major ports of Greece. Transp. Res. Part D Transp. Environ. 2015, 36, 10-17. [CrossRef]

30. Tichavska, M.; Tovar, B. Port-city exhaust emission model: An application to cruise and ferry operations in Las Palmas Port. Transp. Res. Part A Policy Pract. 2015, 78, 347-360. [CrossRef]

31. Fan, Q.; Zhang, Y.; Ma, W.; Ma, H.; Feng, J.; Yu, Q.; Yang, X.; Ng, S.K.W.; Fu, Q.; Chen, L. Spatial and Seasonal Dynamics of Ship Emissions over the Yangtze River Delta and East China Sea and Their Potential Environmental Influence. Environ. Sci. Technol. 2016, 50, 1322-1329. [CrossRef]

32. Papaefthimiou, S.; Maragkogianni, A.; Andriosopoulos, K. Evaluation of cruise ships emissions in the Mediterranean basin: The case of Greek ports. Int. J. Sustain. Transp. 2016, 10, 985-994. [CrossRef]

33. Li, C.; Yuan, Z.; Ou, J.; Fan, X.; Ye, S.; Xiao, T.; Shi, Y.; Huang, Z.; Ng, S.K.; Zhong, Z.; et al. An AIS-based high-resolution ship emission inventory and its uncertainty in Pearl River Delta region, China. Sci. Total Environ. 2016, 573, 1-10. [CrossRef]

34. Lee, M.-W.; Lee, H.-S. A study on atmospheric dispersion pattern of ship emissions-Focusing on Port of Busan. J. Korea Port. Econ. Assoc. 2018, 34, 35-49. [CrossRef]

35. Busan Port Authority Busan Port Status. Available online: https://www.busan.go.kr/ocean/oceanstatus (accessed on 17 December 2021).

36. Manisalidis, I.; Stavropoulou, E.; Stavropoulos, A.; Bezirtzoglou, E. Environmental and health impacts of air pollution: A Review. Front. Public Health 2020, 8, 14. [CrossRef] [PubMed]

37. Marine Traffic. Available online: https://www.marinetraffic.com/en/ais/home/centerx:-12.0/centery:25.0/zoom:4 (accessed on 17 December 2021).

38. Institute, K.M. Vessel Traffic by Ship Type. Available online: https: / / www.kmi.re.kr/web / contents / contentsView.do?rbsIdx=221 (accessed on 17 December 2021).

39. Vessel Finder. Available online: https:/ / www.vesselfinder.com/(accessed on 14 December 2021).

40. ITTC. ITTC-Recommended Procedures and Guidelines, 7.5-02-02-01 Resistance Test. ITTC Qual. Syst. Man. Recomm. Proced. Guidel. 2017, 26, 112-148. Available online: https:/ /ittc.info/media/1217/75-02-02-01.pdf (accessed on 14 December 2021).

41. Kristensen, H.O.; Lützen, M. Prediction of resistance and propulsion power of ships. Proj. No. 2010-56 Emiss. 2013. Available online: https://www.google.com.hk/url?sa=t\&rct=j\&q=\&esrc=s\&source=web\&cd=\&ved=2ahUKEwi5wLyZ1en0AhVmr1 YBHVAfDjoQFnoECAUQAQ\&url=https\%3A\%2F\%2Fwww.danishshipping.dk\%2Fen\%2Fservices\%2Fberegningsvaerktoejer\% 2Fdownload\%2FBasic_Model_Linkarea_Link\%2F163\%2Fwp-2-report-4-resistance-and-propulsion-power.pdf\&usg=AOvVaw2 5ATJeysXA0IBylpW4fEeE (accessed on 14 December 2021).

42. United States Environmental Protection Agency (U.S.EPA), Analysis of Commercial Marine Vessels Emissions and Fuel Consumption Data (EPA420-R-00-002); 2000. Available online: https://nepis.epa.gov/Exe/ZyNET.exe/P1009Z2K.TXT?ZyActionD= ZyDocument\&Client=EPA\&Index=2000+Thru+2005\&Docs=\&Query=\&Time=\&EndTime=\&SearchMethod=1\&TocRestrict $=$ n\&Toc $=\&$ TocEntry $=\& Q F i e l d=\& Q F i e l d$ Year $=\& Q$ FieldMonth $=\& Q F i e l d D a y=\& I n t Q F i e l d O p=0 \& E x t Q F i e l d O p=0 \& X m l Q u e r y=$ \&File=D\%3A \%5Czyfiles\%5CIndex\%20Data\%5C00thru05\%5CTxt \%5C00000027\%5CP1009Z2K.txt\&User=ANONYMOUS\& Password=anonymous\&SortMethod=h\%7C-\&MaximumDocuments=1\&FuzzyDegree=0\&ImageQuality=r75g8/r75g8/x1 50y150g16/i425\&Display=hpfr\&DefSeekPage=x\&SearchBack=ZyActionL\&Back=ZyActionS\&BackDesc=Results $\% 20$ page \& MaximumPages $=1 \& Z y$ Entry $=1 \&$ SeekPage $=x \& Z y P U R L$ (accessed on 14 December 2021).

43. (U.S.EPA), U.S.E.P.A. Control of Emissions from Marine SI and Small SI Engines, Vessels, and Equipment (EPA420-R-08014); 2008. Available online: https:// cfpub.epa.gov/si/si_public_file_download.cfm?p_download_id=499576 (accessed on 14 December 2021). 
44. Ebi, K.L.; Hallegatte, S.; Kram, T.; Arnell, N.W.; Carter, T.R.; Edmonds, J.; Kriegler, E.; Mathur, R.; O’Neill, B.C.; Riahi, K.; et al. A new scenario framework for climate change research: Background, process and future directions. Clim. Chang. 2013, 122, 363-372. [CrossRef]

45. Molland, A.F.; Turnock, S.R.; Hudson, D.A. Ship Resistance and Propulsion: Practical Estimation of Ship Propulsive Power; Cambridge University Press: Cambridge, UK, 2011; ISBN 9780511974113. Available online: https:/ / www.amazon.co.jp/Ship-ResistancePropulsion-Estimation-Propulsive-ebook/dp/B0744L3GMT (accessed on 14 December 2021).

46. Chakraborty, S. How the power requirement of A ship is estimated. In Marineinsight; Marine Insight: Bangalore, India, 2021. Available online: https://www.google.com.hk/url?sa=t\&rct=j\&q=\&esrc=s\&source=web\&cd=\&cad=rja\&uact= 8\&ved=2ahUKEwiotMj31en0AhVXqFYBHSmwCDoQtwJ6BAgJEAM\&url=https $\% 3 \mathrm{~A} \% 2 \mathrm{~F} \% 2 \mathrm{Fwww}$.marineinsight.com $\%$ 2Fnaval-architecture\%2Fpower-requirement-ship-estimated\%2F\&usg=AOvVaw39aWh57I9zRrv9h75eZURJ (accessed on 14 December 2021).

47. Harvald, S. Resistance and Propulsion of Ships; WILEY: New York, NY, USA, 1983. Available online: https: / / www.sciencedirect. com/science/article/abs/pii/0191260784900244?via\%3Dihub (accessed on 14 December 2021).

48. Nicewicz, G.T.D. Assessment of marine auxiliary engines load factor in ports. Manag. Syst. Prod. Eng. 2021, 3, $12-17$.

49. Agency, U.S.E.P. Current Methodologies in Preparing Mobile Source Port-Related Emission Inventories Final Report April 2009; 2009. Available online: https://www.epa.gov/moves/current-methodologies-preparing-mobile-source-port-related-emissioninventories-final-report (accessed on 14 December 2021). 